\title{
Critical Analysis of Financial Crisis on Micro Finance in Reference with India
}

\author{
Kajal J. Savaliya \\ K. K. Parekh Commerce College-Amreli
}

\begin{abstract}
In a country like India where 70 percent of its population lives in rural area and 60 percent depend on agriculture (according to the World Bank reports), micro-finance can play a vital role in providing financial services to the poor and low income individuals. Microfinance is the form of a broad range of financial services such as deposits, loans, payment services, money transfers, insurance, savings, micro-credit etc. to the low and poor individual income. The importance of microfinance in the developing economies like India cannot be undermined, microfinance refers to small savings, credit and insurance services extended to socially and economically disadvantaged segments of society. It is emerging as a powerful tool for poverty alleviation in India. There are two broad approaches that characterize the microfinance sector in India is Self Help Groups (SHGs)-Bank linkage programme and Microfinance Institution (MFIs).This paper tries to outline the prevailing condition of the Microfinance in India in the light of its emergence till now.
\end{abstract}

\section{INTRODUCTION}

Microfinance is beingness practiced as a tool to attack poorness the world over. The terms Microfinance could be characterized as "activity of thrift, achievement and remaining business services and products of very small amounts to the poor in rural area, semiurban or urban areas, enabling them to increase the income slabs and improve their life style". Micro Finance Institute which provide credit, thrift and other finance service \& products of very small amount more to the poor people in rural areas, urban or semi urban area for activating them to raise the income slab and improve life style. Later on the possibility of MFI as auspicious institutions to meet the expenditure and micro enterprise demands of the poor has been realised.

Govt reforms allowed for an growth in commercial banking in India in 1991. The region now has a wide spread and efficient banking set-up with around 1,00,000 branches in country. In India the enlargement of commercial banking has also led to many convenient financial environs for poor. It was reforms that Seld Help Group (SHG), Bank Inheritance grew to embellish a key component of finance for Indian Poor. SHG is association of around 20 women. They provide an possibility for individual to pull the money and after that use those fund to lend small amounts to each other with interest. The fundamental of Micro Finance were founded on the philosophy of cooperation and its centric value of equity, mutual self-help \& equivalence. At the courage of this principle are the conception of human development and the organization of man expressed via team working untidily to accomplish a good life for them selves and their child. so we can see growth of this concept of micro finance on current challenges is to find reliable and efficient ways to provide richer menu products of micro finance. MF is not only extending credit but extend to those who really need for their family survival. It couldn't measured in term of qty but due to weight age to quality measuring. How available credit user to survive and grow with specific means.

\section{TYPES OF FINANCIAL CRISIS}

\section{A. Banking crisis}

It is ambitious for them to quick pay approve all deposit if they will demand, so a run may change the bank in insolvency, causing many depositors to decline savings innless they covered by deposit insurance. A condition in which bank runs distributed is called a systemic banking crisis or just a banking pain. A condition w'out distributed bank runs, in which banks are reluctant to lend, coz they disorder they have deficient fund available is oftentimes called a credit crunch. In this way the banks become an activator of any financial crisis.

\section{B. Speculative bubbles and crashes}

Economists are says that a business quality ex. stock exhibits a bubble when it's price exceed the present value of all future income like dividend, interest etc will be received by it's maturity. If market participant purchase anny asses primarily and sell it in future with high price, instead of buying income will be generate, this could be proof that bubble. If bubble present also have a risk of market crash in asset price. Market will only on buying side as long as they expect other buying and when many decide to sell the price will fall down.

\section{International Financial Crisis}

When a region maintain a exchange rate which is fixed suddenly forced to degrade it's currency coz of a curious attack, which called a balance or currency crisis. When a region fails to pay back it's swayer debt which called sovereign default. While devaluation and default could be conscious decision of the govt, they offer detected to be the automatic result of a change in investor thought that leads to a explosive stop in capital in glow or explosive increase in capital flight.

\section{Wider economic crises}

Negative GDP is development last 2 quarter is called a recession. An especially prolonged ceding may be titled a formation a agelong phase of decelerate but not required negative growing is sometime called economic stagnation. Since these phenomena 


\section{www.ijtsrd.com}

concern often more than financial business they are not commonly advised financial crises.

\section{Literature Review}

Sarmah, G. N and Das, D. K. (2012) attempt to analyze the rule of microfinance and Self-Help Groups (SHG) for the socio economic development of the poor people in Lakhimpur District of Assam. For collecting the primary data a total of 50 SHGs and five (5) members from each SHG $(50 * 5=250$ respondents) were randomly selected covering the entire Lakhimpur District. From the study it has been found that after joining the SHGs the poor rural people can increase their income and improve their standard of living by performing economic activities independently.

Vijender, A. et al. (2012) 11 stresses on rising farm place efficiency through micro finance and micro insurance in achieving their economic and social goals, which at here ascertain eff largely identified only constricted success. The finding shows micro finance institutions (MFIs) have to become steady profitable to trim down poverty and role of state government in crucial in augmenting farm investment, micro financing, micro insurance, facilitating private investment and spreading institutions to help the poor in realizing inclusive growth of the India.

Kulshrestha, A. C. (2011) examines the problem of menstruation the uncoordinated facet and explains the way understood by the Amerindian Fundamental Statistical Power in status of the line it generates and its contribution to evaluate side. The judgment shows that it is intrinsically to alter surveys on expostulatory aspect activities to provide author tried accumulation in sect to aid a straight laced reasoning of the mechanics of uncoordinated sector.

Moses, E. (2011) focus on the origin and concept of micro finance, features and role of microfinance in India, reviewing the progress and weakness followed by suggestion for making micro finance as an effective instrument of poverty elevation, women empowerment and rural development in India. The finding shows micro finance is being viewed as one of the most powerful tools for uplifting the economic conditions of the asset-less poor through group approach that ensures active participation and involvement of the beneficiaries in effective implementation of the program.

International Monitory fund- Di Bella, Gabriel The global financial crisis affected microfinance institutions (MFIs) as lending growth was constrained by scarcer borrowing opportunities, while the efficient slowdown negatively impacted plus lineament and gain. It also brought to the anterior the relatively high worry rates that MFIs dictation to their (low- income) customers. This product revisits the issuing of systemic venture of MFIs, and finds that opposition to the information before the crisis, MFI show is correlated not only to retainer scheme conditions but also to changes in multinational city markets. It also presents an existential analysis of loaning rates with the usefulness of disclosure contract decisions, and finds that word sizes, fecundity, and MFI age boost to vindicate differences in lending value levels. This suggests that rule (and policies) promoting MFI competition and creativity in lending rates.

Jacques Attali, Economist According to Mr. Attali, who is Chair of PlaNet Direction, micro-credit plays a key role in use efforts targeting the worst segments of the aggregation, and micro-finance sources requirement to be desiccated at a experience when the worldwide financial crisis is gravely touching Continent. The europe has made steadied move over the parthian decade, building the foundations for higher growing rates and impoverishment change.

Cull, R. et al. (2007) explore the graph of gain, give defrayment and expenditure change with unusually high-quality accumulation on 124 institutions in 49 countries. The find shows the construct of earning profits spell serving the resource less, but a trade-off emerges between profitability and bringing the poorest. Rearing fees to really piercing levels does not ensure greater gain and the benefits of value knifelike lessen when bringing better-off customers.

CGAP: Consultative Group to Assist the Poor The global financial crisis is spreading quickly in emerging markets, but little is known about its impact on microfinance sector. CGAP surveyed MFIs in Territory 2009 varan the result of the crisis. Argue from MIX, the microcredit summit operation, and voluminous MFI networks enabled full airing. Over 400 MFI managers responded, providing a near content of regions and institutional sizes. MFI managers from institutional many moved than remaining might change much incentives to move, so this analysis recognizes the essay of self action prepossess.

\section{RESEARCH METHODOLOGY}

\section{Objective of the Study}

- To analyses the impact of global financial crisis on micro finances.

- The goal of microfinance is to reduce poverty.

- Focuses on business performance and household income to establish a link between the availability of microfinance and overall wellbeing of the poor.

- To know how institution cope up with the global financial crisis.

- To analyses risk, help \& support of microfinance business.

Hypothesis 


\section{www.ijtsrd.com}

Ho: Performance of microfinance is dependant from global financial crisis

Ha: Performance of microfinance is independent from global financial crisis

\section{Research Design}

\begin{tabular}{|l|l|}
\hline SOURCE OF DATA & $\begin{array}{l}\text { - Primary Data } \\
\text { - Secondary Data }\end{array}$ \\
\hline $\begin{array}{l}\text { DATA COLLECTION } \\
\text { METHOD }\end{array}$ & - Descriptive Study \\
\hline POPULATION & - Exploratory Study \\
\hline SAMPLING METHOD & - 10 Financial Institution \\
\hline SAMPLING FRAME & - Convenience \\
\hline $\begin{array}{l}\text { DATA COLLECTION } \\
\text { INSTRUMENTS }\end{array}$ & - Saurashtra Zone(Amreli) \\
\hline
\end{tabular}

\section{Data Analysis}

\section{Type of institute....}

( ) Co-operative bank ( ) Microfinance Institution ( ) Private Institution

2. Which type of microfinance services will you provide to customer?

( ) Loans ( ) Savings ( ) Micro insurance ( ) Micro credit ( ) Remittance

\section{Your organization primary works in which area?}

( ) In village or rural area ( ) In a city or urban area ( ) Trough out a single country

\section{Which financial crisis effect to the microfinance (give} rank)

( ) Recession ( ) Slumps ( ) Downturn ( ) Credit Crunch ( ) Interest rate

\section{What is the Impact of global Financial Crisis?}

( ) job losses ( ) Credit Crunch ( ) widespread of Downturn ( ) falling demand

( ) Impact on Urban poor

6. Is any other crisis having institute face instead of the above?

Specify,

7. To which type of customer institute give the services of micro finance?

( ) Small Business ( ) Women ( ) Agriculture Business ( ) Investor ( ) Small Firms

8. What is your aim for providing this kind of services? (Give rank)

( ) crisis prevention ( ) Government norms ( ) Women development ( ) Reduce poverty

( ) Reduce income inequality ( ) Agriculture/rural development ( ) Urban development

9. Is government helping to your institution for micro finance services?
( ) Yes
( ) No

10. Did your institution face financial difficulties due to the global financial crisis?

( ) Yes

( ) No

11. Do you think that micro finance is one of the risk businesses?
( ) Yes
( ) Don't know
( ) No
( ) Can't say

12. What effects you put for reduce impact of global financial crisis to your business?

( ) Liquidity maintain ( ) Joint with other institute ( ) Security maintain ( ) RBI help/ support ( ) Government support ( ) Others

HYPOTHESIS TESTING 
Ho: Performance of microfinance is dependant from global financial crisis

Ha: Performance of microfinance is independent from global financial crisis

\begin{tabular}{|l|c|c|c|c|c|}
\hline $\begin{array}{l}\text { Source of } \\
\text { Variation }\end{array}$ & SS & d.f. & MS & f- ratio & $\begin{array}{r}\mathbf{5 \%} \\
\text { limit }\end{array}$ \\
\hline $\begin{array}{l}\text { Between } \\
\text { Sample }\end{array}$ & 0.4 & $\begin{array}{c}(5- \\
1)=4\end{array}$ & $\begin{array}{c}0.4 / 4= \\
0.1\end{array}$ & $\begin{array}{r}0.1 / 6.78 \\
=\end{array}$ & $\begin{array}{c}\text { F } \\
(4,20) \\
=2.87\end{array}$ \\
\hline Within & & $\begin{array}{c}(25- \\
5)=\end{array}$ & $\begin{array}{c}135.6 / 20 \\
=6.78\end{array}$ & & \\
Sample & 135.6 & 20 & & & \\
\hline Total & 136 & & & & \\
\hline
\end{tabular}

Calculated value $=0.0147$ Tabulated value $=2.87$

$\mathbf{5 \%}$ level of significance $0.0147<2.87$

So, test is insignificance. And $\mathbf{H O}$ is accepted.

\section{FINDINGS}

- From our study we have founded that Micro Finance has prove to be an effective tool in India for the purpose of eradicating poverty through various models and also due to the enormous growth of Micro Finance Institutes in India especially SKS Micro Finance Ltd. And others. Also SIDBI \& NABARD have contributed much to the development of the Indian Micro Finance sector.

- On the study of the report we have founded that micro finance institution provide several service like loans, savings, micro insurance and etc. to promote the microfinance.

- The MFIs and other financial institution generally in village or rural areas for reduce poverty and enhance value of microfinance.

- On the bases of our study that, several financial crisis effect to micro finance. Which was prevailing by the lack of funding, changes in interest rate and etc. on the bases of whole study the result shows that a microfinance are mostly effected by the changing interest rate.

- The study also represent that government will support to all financial institution. Government builds some norms for a institution

- to compulsory provide $35 \%$ of microfinance services. Institution will provide services more to agriculture business and to small business.

- The impact of global financial crisis is more to microfinance as well as negative impact of them is to job losses, credit crunch, falling demand and etc.

- The study shows that the role of government play vital role in enhancing the microfinance programme by supporting microfinance institution.

- Due to the crisis some institution was face financial difficulty and some are run smoothly.

- Microfinance put some efforts to cop up with global financial crisis such as; security maintain, liquidity maintain and take a government support.

- The one important point of microfinance is that they are not drifting away from their customers.

\section{LIMITATION OF THE STUDY}

In study, observed that all institution have not totally aware about the global financial crisis. Micro Finance has done well in providing assistance to the rural people and people residing in urban areas with low income but there are certain limitations associated with our work. It is also very difficult to carry out the project work simultaneously with the study work as the focus is to be widened and equal work is to be done to both these works. Collect all information by primary data the use of questionnaire but there are lacks of some adequate information. This study considered limited respondents because of the time limit and on the bases of institute's response.

\section{SUGGESTIONS}

1. To cope up with financial crisis micro finance institution have to maintain the liquidity. 
International Journal of Trend in Scientific Research and Development, Volume 1(2), ISSN: 2456-6470 www.ijtsrd.com

2. To prevent a financial crisis and reduce poverty micro finance has to give several services.

3. Some financial institution have to change the mentality of that micro finance business is a risk business.

4. Microfinance institutions have to take major support of other institution, RBI and NABARD.

5. Establish more micro finance Institutions in Saurashtra Zone
3. M S Sriram and Rajesh Upadhyayula The Transformation of Microfinance in India: Experiences, Options and Future

4. www.indiamicrofinance.com/

5. www.rbi.org.in

6. http://study-material4u.blogspot.in/2012/07/chapter-4micro-finance-in-india.html

7. http://indiamicrofinance.com/microfinance-portfolioin-india-pegged-at-rs-50000-crore.html

8. http://rbidocs.rbi.org.in/ $\mathrm{r}$ docs/Publications/PDFs/88

9. http://www.samn.eu/?q=mfindia

\section{REFERENCES}

1. Bhandari, Amit K., \& Kundu, A.(2014). Microfinance, Risk-taking Behaviour and Rural Livelihood

2. Dutt, Ruddar and Sundharam, K.P.M (2004): Indian economy S. Chand and Company publication,India. 